\title{
INTERACTIVE EFFECTS OF VERMICOMPOST AND SEED TUBER SIZE ON THE PRODUCTION OF POTATO (SOLANUM TUBEROSUM L.)
}

\author{
Maruf Mostofa*, Tuhin Suvra Roy ${ }^{1}$ and Rajesh Chakraborty ${ }^{1}$ \\ Institute of Seed Technology, Sher-e-Bangla Agricultural University, \\ Dhaka-1207, Bangladesh
}

Keywords: Interactive effects, Potato, Tuber size, Vermicompost, Yield

\begin{abstract}
An experiment was conducted to find out the effect of vermicompost and seed tuber size on the yield of Potato. The experiment consisted of two factors, i.e., factor A: Vermicompost level (Vc-4): $\mathrm{Vc}_{1}: 0 \mathrm{t} / \mathrm{ha}, \mathrm{Vc}_{2}$ : 3 t/ha, $\mathrm{Vc}_{3}: 6 \mathrm{t} / \mathrm{ha}$ and $\mathrm{Vc}_{4}: 9 \mathrm{t} / \mathrm{ha}$; factor B: Tuber size (T-5): $\mathrm{T}_{1}: 5-10 \mathrm{~g}, \mathrm{~T}_{2}: 10-20 \mathrm{~g}, \mathrm{~T}_{3}: 20-30 \mathrm{~g}, \mathrm{~T}_{4}: 30-$ $40 \mathrm{~g}$ and $\mathrm{T}_{5}:>40 \mathrm{~g}$. Vermicompost was found to have a significant effect on most of the yield contributing parameters. Results showed that yield parameters increased with increasing vermicompost level irrespective of tuber size. Among the 20 treatment combinations, vermicompost @ $9 \mathrm{t} / \mathrm{ha}$ with tuber size $>40 \mathrm{~g}$ produced the maximum yield ( $31.33 \mathrm{t} / \mathrm{ha}$ ) that was $216.82 \%$ higher than $\mathrm{Vc}_{1} \mathrm{~T}_{1}$.
\end{abstract}

Potato (Solanum tuberosum L.) belonging to the Solanaceae is cultivated in nearly 150 countries and is the world's single most vital tuberous crop with an important role in the global food network and food security (Singh 2010). It is the world's fourth-largest crop after maize, wheat and rice.

In Bangladesh, its position is 2nd after rice in production (FAOSTAT 2020). The total area under potato crop, per ha yield and total production in Bangladesh were 477,419 hectares, 22.50 t/ha and 9,744,412 metric ton respectively (FAOSTAT 2020). The total production is increasing day by day because it is a substitute food crop against rice and wheat and is a nutrient-rich crop (BBS 2015). Potato is unique compared to other vegetables in that they are exclusively consumed in processed forms. Approximately $60 \%$ of the fresh potato crop is used for industrial processing into products such as French fries and chips, whereas the remaining $40 \%$ is sold on the fresh market for home preparation and fresh food service applications (USDA 2014). Due to the increasing demand of consumers and foreign importers on this important crop, special attention should be given to increase its yield.

The area and production of potato in Bangladesh have been increasing during the last decades but the yield per unit area remains more or less static. Nowadays gradual deficiencies in soil organic matter and reduced yield of the crop are an alarming problem in Bangladesh. The cost of inorganic fertilizers is very high. On the other hand, the organic manure is easily available to the farmers and its cost is low compared to that of inorganic fertilizers. Vermicompost (organic manure) can play an important role in potato productivity. Senesi et al. (1996) mentioned that vermicomposting is a controlled, aerobic, biological process and able to convert biodegradable humus like organic substances and suitable for the application of soil amendment. It is a good source of different macro and micronutrients particularly NPKS. It contains organic carbon 9.5 $17.98 \%$, nitrogen $0.5-1.50 \%$, phosphorous $0.1-0.30 \%$, potassium $0.15-0.56 \%$, sodium 0.06 $0.30 \%$, sulphur $128-548 \mathrm{mg} / \mathrm{kg}$, copper $2-9.50 \mathrm{mg} / \mathrm{kg}$, zinc $5.70-11.50 \mathrm{mg} / \mathrm{kg}$, calcium and magnesium 22.67 - $47.60 \mathrm{meq} / 100 \mathrm{~g}$ (Sinha et al. 2009). It also increases microbial activity, which

*Author for correspondence: <marufsau@ @otmail.com>. ${ }^{1}$ Department of Agronomy, Faculty of Agriculture, Sher-e-Bangla Agricultural University, Dhaka-1207, Bangladesh. 
improves the availability of soil phosphorous and nitrogen (Senapati et al. 1992). It can reduce the mining of soil nutrients and improve soil organic matter, humus and overall soil productivity (Jenssen 1993). Soil organic matter acts as "cement" like agent for water holding clay and soil particles together, this contributing to the crumb structure of the soil providing resistance against soil erosion, binds micronutrient metal ions in the soil to check leaching out of surface soils. Organic constituents in the humic substances also act as plant growth stimulants (Jenssen 1993). It has many outstanding biological properties. They are rich in bacteria, actinomycetes, fungi and cellulose-degrading bacteria (Werner and Cuevas 1996). The use of seed tuber from True Potato Seed (TPS) for potato production has increased recently in Europe, North America and Asia, especially in the developing countries (Burton 1989). This is due to the low transmission of disease, high multiplication rate and good tuber yield. In Bangladesh, this technology has been highly promising (Siddique and Rashid 2000). Applications of vermicompost singly or in combination with either other chemical fertilizers have been proved effective to enhance yield (Alam et al. 2007). So, using different amounts of vermicompost materials may put contribution to improving the yield of potato in Bangladesh's condition. Since effects of vermicompost and seed tuber size on the yield of potato derived from TPS is still unknown, thus an attempt was taken to investigate the effect of vermicompost and seed tuber size on the yield of potato.

The experimental work was conducted at the research field of Sher-e-Bangla Agricultural University, Dhaka-1207 during 1 November, 2014 to 30 April, 2015 and 1 November, 2015 to 30 April, 2016 in Rabi season (winter). The experimental area was located at $23^{\circ} 77^{\prime} \mathrm{N}$ latitude and $90^{\circ} 38^{\prime} \mathrm{E}$ longitudes and at an altitude of $8.6 \mathrm{~m}$ from the sea level and the area was under the Agro-ecological Zone (AEZ-28) and belonged to the Madhupur Tract (Brammer et al. 1988). The soil of the research field was general soil type series of shallow red-brown terrace soil under Tejgaon series. Upper-level soils were clay loam in texture, olive-gray through common fine to medium distinct dark yellowish-brown mottles. Soil pH was 5.6 and had organic carbon $0.45 \%$. Sufficient sunshine, irrigation and drainage facility was available during the experimental period. The experiment consisted of two factors viz., (a): Vermicompost level $\left(\mathrm{Vc}_{1}: 0 \mathrm{t} / \mathrm{ha} ; \mathrm{Vc}_{2}: 3 \mathrm{t} / \mathrm{ha}\right.$; $\left.\mathrm{Vc}_{3}: 6 \mathrm{t} / \mathrm{ha} ; \mathrm{Vc}_{4}: 9 \mathrm{t} / \mathrm{ha}\right)$ and (b): Seedling tuber size $\left(\mathrm{T}_{1}: 5-10 \mathrm{~g} ; \mathrm{T}_{2}: 10-20 \mathrm{~g} ; \mathrm{T}_{3}: 20-30 \mathrm{~g} ; \mathrm{T}_{5}:>\right.$ $40 \mathrm{~g}$ ). The seedling tuber of BARI TPS-1 was used for the study. The experiment was laid out in a split-plot design with 3 replications. Vermicompost was assigned to the main plot and seedling tuber size to the subplot. The distance between row to row was $50 \mathrm{~cm}$ and the plant to plant was $25 \mathrm{~cm}$. The distance between plot to the plot was $75 \mathrm{~cm}$. The size of the unit plot was $2 \mathrm{~m} \times 1.5 \mathrm{~m}$. The allocated plots were fertilized by recommended doses of urea, muriate of potash (MOP), triple super phosphate (TSP), zinc sulfate, gypsum and boric acid (Mondal et al. 2011) except treatment. The total amount of vermicompost was applied at 7 days before planting as per treatment. Data on different yield parameters viz., No. of tuber/hill, weight of tuber/hill, average tuber weight, yield (t/ha), marketable yield (t/ha), non-marketable yield (t/ha), seed potato yield (t/ha) and non-seed potato yield (t/ha) were determined.

The same study was conducted under the same treatment under the same field condition in both year and finally, the means were taken from those two experiments. Statistix 10 (version 2013) computer package was applied for analysis following ANOVA technique and means were compared by LSD at 5\% level of probability (Gomez and Gomez 1984).

Significant variation was observed among different levels of vermicompost on number of tubers/hill. The maximum (11.57) number of tubers was found from $\mathrm{Vc}_{2} \mathrm{~T}_{4}$ which was statistically similar to $\mathrm{Vc}_{2} \mathrm{~T}_{5}, \mathrm{Vc}_{2} \mathrm{~T}_{2}$ and $\mathrm{Vc}_{2} \mathrm{~T}_{1}$. The minimum (8.39) number of tubers was obtained from $\mathrm{Vc}_{4} \mathrm{~T}_{3}$ which was statistically similar to $\mathrm{Vc}_{1} \mathrm{~T}_{1}$ (Table 1). Batra et al. (1992) indicated that tuber number/plant increased with an increase in seedling tuber size. The highest tuber number/plant was recorded in $20-40 \mathrm{~g}$ size seedling tuber planted crops. The number of main stems/plant has a 
positive bearing on number of tubers/plant. TPS seedling tubers have a tendency to produce a greater number of tubers/plant (Adhikari 2005). Harsharin et al. (1983) have reported that the number of tubers/plant increased by increasing the size of seed tubers from $25-35$ to $35-45$ and $45-55 \mathrm{~mm}$.

Table 1. Effcet of vermicompost and seed tuber size on yield and yield contributing characters of potato (Pooled data from two years study and means were taken-2014-2016).

\begin{tabular}{|c|c|c|c|c|c|c|c|c|}
\hline $\begin{array}{l}\text { Combina- } \\
\text { tions }\end{array}$ & $\begin{array}{c}\text { No. of } \\
\text { tubers/ } \\
\text { hill }\end{array}$ & $\begin{array}{l}\text { Av. tuber } \\
\text { weight } \\
\text { (g) }\end{array}$ & $\begin{array}{l}\text { Weight of } \\
\text { tuber/hill } \\
(\mathrm{kg})\end{array}$ & $\begin{array}{l}\text { Tuber } \\
\text { yield } \\
\text { (t/ha) }\end{array}$ & $\begin{array}{c}\text { Marketable } \\
\text { yield } \\
\text { (t/ha) }\end{array}$ & $\begin{array}{c}\text { Non- } \\
\text { marketable } \\
\text { yield } \\
\text { (t/ha) }\end{array}$ & $\begin{array}{c}\text { Seed } \\
\text { potato } \\
\text { yield } \\
(\mathrm{t} / \mathrm{ha})\end{array}$ & $\begin{array}{c}\text { Non-seed } \\
\text { potato } \\
\text { yield } \\
\text { (t/ha) }\end{array}$ \\
\hline $\mathrm{Vc}_{1} \mathrm{~T}_{1}$ & $8.95 \mathrm{hi}$ & $34.58 \mathrm{q}$ & $309.64 \mathrm{k}$ & $14.45 \mathrm{k}$ & $10.49 p$ & $3.96 \mathrm{ij}$ & $7.60 \mathrm{q}$ & $6.85 \mathrm{~h}$ \\
\hline $\mathrm{Vc}_{1} \mathrm{~T}_{2}$ & $9.76 \mathrm{e}-\mathrm{g}$ & $37.09 \mathrm{p}$ & $361.93 \mathrm{j}$ & $16.89 \mathrm{j}$ & $12.78 \mathrm{o}$ & $4.11 \mathrm{~h}$ & $9.32 \mathrm{p}$ & $7.57 \mathrm{f}$ \\
\hline $\mathrm{Vc}_{1} \mathrm{~T}_{3}$ & $10.60 \mathrm{~b}-\mathrm{d}$ & $38.02 \mathrm{o}$ & $402.86 \mathrm{i}$ & $18.80 \mathrm{i}$ & $13.92 n$ & $4.88 \mathrm{a}$ & 9.79 o & $9.01 \mathrm{c}$ \\
\hline $\mathrm{Vc}_{1} \mathrm{~T}_{4}$ & $10.49 \mathrm{~cd}$ & $39.35 n$ & $412.71 \mathrm{i}$ & $19.26 \mathrm{i}$ & $14.63 \mathrm{~m}$ & $4.63 \mathrm{~cd}$ & $10.00 \mathrm{n}$ & $9.26 \mathrm{~b}$ \\
\hline $\mathrm{Vc}_{1} \mathrm{~T}_{5}$ & $10.72 \mathrm{~b}-\mathrm{d}$ & $39.82 \mathrm{~m}$ & $426.71 \mathrm{i}$ & $19.91 \mathrm{i}$ & 15.131 & $4.78 \mathrm{~b}$ & 13.741 & $6.17 \mathrm{j}$ \\
\hline $\mathrm{Vc}_{2} \mathrm{~T}_{1}$ & $11.09 \mathrm{a}-\mathrm{c}$ & 41.401 & $459.02 \mathrm{~h}$ & $21.42 \mathrm{~h}$ & $16.91 \mathrm{k}$ & $4.51 \mathrm{e}$ & $14.78 \mathrm{j}$ & $6.64 \mathrm{i}$ \\
\hline $\mathrm{Vc}_{2} \mathrm{~T}_{2}$ & $11.11 \mathrm{a}-\mathrm{c}$ & $42.01 \mathrm{k}$ & $466.64 \mathrm{gh}$ & $21.78 \mathrm{gh}$ & $17.11 \mathrm{k}$ & $4.67 \mathrm{c}$ & $14.55 \mathrm{k}$ & $7.23 \mathrm{~g}$ \\
\hline $\mathrm{Vc}_{2} \mathrm{~T}_{3}$ & $10.58 \mathrm{~b}-\mathrm{d}$ & $44.95 \mathrm{j}$ & $475.62 \mathrm{f}-\mathrm{h}$ & $22.20 \mathrm{f}-\mathrm{h}$ & $17.99 \mathrm{j}$ & $4.21 \mathrm{~g}$ & $12.44 \mathrm{~m}$ & $9.76 \mathrm{a}$ \\
\hline $\mathrm{Vc}_{2} \mathrm{~T}_{4}$ & $11.57 \mathrm{a}$ & $45.08 \mathrm{j}$ & $521.64 \mathrm{de}$ & $24.34 \mathrm{de}$ & $19.71 \mathrm{gh}$ & $4.63 \mathrm{~d}$ & $18.01 \mathrm{f}$ & $6.33 \mathrm{j}$ \\
\hline $\mathrm{Vc}_{2} \mathrm{~T}_{5}$ & $11.18 \mathrm{ab}$ & $46.25 \mathrm{i}$ & $517.14 \mathrm{de}$ & $24.13 \mathrm{de}$ & $19.78 \mathrm{gh}$ & $4.35 \mathrm{f}$ & $14.70 \mathrm{j}$ & $9.43 \mathrm{~b}$ \\
\hline $\mathrm{Vc}_{3} \mathrm{~T}_{1}$ & $10.09 \mathrm{~d}-\mathrm{f}$ & $48.71 \mathrm{~h}$ & $491.60 \mathrm{e}-\mathrm{g}$ & $22.94 \mathrm{e}-\mathrm{g}$ & $19.05 \mathrm{i}$ & $3.89 \mathrm{k}$ & $17.43 \mathrm{~g}$ & $5.51 \mathrm{k}$ \\
\hline $\mathrm{Vc}_{3} \mathrm{~T}_{2}$ & $10.18 \mathrm{~d}-\mathrm{f}$ & $49.03 \mathrm{~h}$ & 499.07 ef & 23.29 ef & $19.32 \mathrm{~h}$ & $3.97 \mathrm{i}$ & $16.48 \mathrm{i}$ & $6.81 \mathrm{hi}$ \\
\hline $\mathrm{Vc}_{3} \mathrm{~T}_{3}$ & $10.28 \mathrm{de}$ & $49.81 \mathrm{~g}$ & $512.21 \mathrm{de}$ & $23.90 \mathrm{de}$ & $20.08 \mathrm{~g}$ & 3.821 & $16.79 \mathrm{~h}$ & $7.11 \mathrm{~g}$ \\
\hline $\mathrm{Vc}_{3} \mathrm{~T}_{4}$ & $10.59 \mathrm{~b}-\mathrm{d}$ & $57.87 \mathrm{~d}$ & $612.64 \mathrm{~b}$ & $28.59 \mathrm{~b}$ & $23.64 \mathrm{~d}$ & 3.811 & $21.11 \mathrm{~d}$ & $7.48 \mathrm{f}$ \\
\hline $\mathrm{Vc}_{3} \mathrm{~T}_{5}$ & $9.63 \mathrm{fg}$ & $66.57 \mathrm{c}$ & $641.07 \mathrm{ab}$ & $29.92 \mathrm{ab}$ & $25.37 \mathrm{c}$ & $3.92 \mathrm{j}$ & $22.08 \mathrm{c}$ & $7.84 \mathrm{~d}$ \\
\hline $\mathrm{Vc}_{4} \mathrm{~T}_{1}$ & $9.60 \mathrm{f}-\mathrm{h}$ & $53.90 \mathrm{f}$ & $517.29 \mathrm{de}$ & $24.14 \mathrm{de}$ & $20.28 \mathrm{~g}$ & $3.86 \mathrm{kl}$ & $16.91 \mathrm{~h}$ & $7.23 \mathrm{~g}$ \\
\hline $\mathrm{Vc}_{4} \mathrm{~T}_{2}$ & 9.70 e-g & $54.97 \mathrm{e}$ & $533.36 \mathrm{~d}$ & $24.89 \mathrm{~d}$ & $20.91 \mathrm{f}$ & $3.98 \mathrm{i}$ & $17.25 \mathrm{~g}$ & $7.64 \mathrm{ef}$ \\
\hline $\mathrm{Vc}_{4} \mathrm{~T}_{3}$ & $8.39 \mathrm{i}$ & $67.74 \mathrm{~b}$ & $568.50 \mathrm{c}$ & $26.53 \mathrm{c}$ & $22.81 \mathrm{e}$ & $3.72 \mathrm{~m}$ & $19.32 \mathrm{e}$ & $7.21 \mathrm{~g}$ \\
\hline $\mathrm{Vc}_{4} \mathrm{~T}_{4}$ & $9.53 \mathrm{f}-\mathrm{g}$ & $67.91 \mathrm{~b}$ & $647.43 \mathrm{a}$ & $30.21 \mathrm{a}$ & $26.69 \mathrm{~b}$ & $3.63 n$ & $22.43 \mathrm{~b}$ & $7.78 \mathrm{de}$ \\
\hline $\mathrm{Vc}_{4} \mathrm{~T}_{5}$ & $9.37 \mathrm{gh}$ & $71.66 \mathrm{a}$ & $671.36 \mathrm{a}$ & $31.33 \mathrm{a}$ & $27.59 \mathrm{a}$ & $3.74 \mathrm{~m}$ & $23.37 \mathrm{a}$ & $7.96 \mathrm{~d}$ \\
\hline $\mathrm{CV}(\%)$ & 3.85 & 0.54 & 3.41 & 3.41 & 0.79 & 0.39 & 0.57 & 1.50 \\
\hline $\mathrm{LSD}_{0.05}$ & 0.6579 & 1.1074 & 30.709 & 1.4331 & 0.5934 & 0.0548 & 0.3525 & 0.1864 \\
\hline $\begin{array}{l}\text { Level of } \\
\text { significance }\end{array}$ & $* *$ & $* *$ & $* *$ & $* *$ & $* *$ & $* *$ & $* *$ & $* *$ \\
\hline
\end{tabular}

In a column means having similar letter(s) are statistically similar and those having dissimilar letter(s) differ significantly. ** = Significant at $1 \%$ level of probability; $\mathrm{Vc}_{1}-$ Control, $\mathrm{Vc}_{2}-3 \mathrm{t} / \mathrm{ha}, \mathrm{Vc}_{3}-6 \mathrm{t} / \mathrm{ha}, \mathrm{Vc}_{4}-9 \mathrm{t} / \mathrm{ha}, \mathrm{T}_{1} 5-10 \mathrm{~g}, \mathrm{~T}_{2}-10-20 \mathrm{~g}$, $\mathrm{T}_{3}-20-30 \mathrm{~g}, \mathrm{~T}_{4}-30-40 \mathrm{~g}, \mathrm{~T}_{5}->40 \mathrm{~g}$.

Profound dissimilarity was found among the different combinations of vermicompost levels and tuber sizes on average tuber weight. The highest average tuber weight $(71.66 \mathrm{~g})$ was recorded from $\mathrm{Vc}_{4} \mathrm{~T}_{5}$. The lowest average tuber weight (34.58 g) was obtained from $\mathrm{Vc}_{1} \mathrm{~T}_{1}$ (Table 1). It was observed that plants from smaller seedling tubers mature later than the larger. This may explain the average tuber weight differences between plants from the different seedling tuber size (Adhikari 2005). It may be said that the higher doses of vermicompost have been increased the 
stored product as dry matter in tuber through photosynthesis resulted in higher average weight than the control.

Weight of tuber/hill due to the different combinations of vermicompost levels and tuber sizes was statistically soumd. The highest weight $(671.36 \mathrm{~g})$ of tuber/hill was recorded in $\mathrm{Vc}_{4} \mathrm{~T}_{5}$ which was statistically similar to $\mathrm{Vc}_{4} \mathrm{~T}_{4}$ and $\mathrm{Vc}_{3} \mathrm{~T}_{5}$. The lowest weight $(309.64 \mathrm{~g}$ ) of tuber/hill was from $\mathrm{Vc}_{1} \mathrm{~T}_{1}$ (Table 1). It was observed that plants from smaller seedling tubers mature later than the larger. The larger seedling tuber may have increased the dry matter/hill than the smaller seedling tuber. The increase in yield with the application of vermicompost could be attributed to the corresponding increase in leaf area, which was responsible for synthesizing photosynthetic and increase in weight of tuber (Gangele 2017).

Tuber yield due to the different combinations of vermicompost levels and tuber sizes was found to be statistically significant. The highest tuber yield (31.33 t/ha) was recorded from $\mathrm{Vc}_{4} \mathrm{~T}_{5}$ which was statistically similar to $\mathrm{Vc}_{4} \mathrm{~T}_{4}$ and $\mathrm{Vc}_{3} \mathrm{~T}_{5}$. The lowest $(14.45 \mathrm{t} / \mathrm{ha})$ tuber yield was from $\mathrm{Vc}_{1} \mathrm{~T}_{1}$ (Table 1). The variation might be due to better plant growth and average tuber weight. The weight of the TPS seedling tubers significantly affected the total tuber yields. The significantly maximum total tuber yield was obtained when larger seedling tubers were planted. Seedling tuber 20 - $40 \mathrm{~g}$ size produced the highest total $\left(30.93 \mathrm{t} \mathrm{ha}^{-1}\right.$ ) (Adhikari 2005). An increase in seedling tuber size gradually increased the yield of tubers. It was primarily due to high food reserve in large seed tubers which ultimately contributed to produce high yield through increased vegetative growth of plants and the development of tubers (Sultana et al. 2001). The increase in tuber yield was due to the fact that vermicompost has high porosity, aeration drainage and water-holding capacity which effected on tuber development and total yield (Joshi et al. 2015).

Noticeable variation was observed among the different combinations of vermicompost levels and tuber sizes on marketable tuber yield. The highest marketable tuber yield $(27.59 \mathrm{t} / \mathrm{ha})$ was observed from $\mathrm{Vc}_{4} \mathrm{~T}_{5}$ and the lowest (10.49 t/ha) was observed from $\mathrm{Vc}_{1} \mathrm{~T}_{1}$ (Table 1). Marketable tuber yield increase due to vermicompost at higher levels may be associated with the increment of total tuber yield and also due to the increment of the proportion of large tuber yield percentage. Seedling tuber 20 - $40 \mathrm{~g}$ size produced the highest marketable yield (27.14 t/ha) (Adhikari 2005).

Significant dissimilarity was observed among the different combinations of vermicompost levels and tuber sizes on non-marketable tuber yield. The highest (4.88 t/ha) non-marketable tuber yield was observed from $\mathrm{Vc}_{1} \mathrm{~T}_{3}$ and the lowest $(3.63 \mathrm{t} / \mathrm{ha})$ non-marketable tuber yield was observed from $\mathrm{Vc}_{4} \mathrm{~T}_{4}$ (Table 1). Non-marketable tuber yield reduction due to vermicompost at higher levels might be associated with the increment of both marketable and total tuber yield and also due to the increment of the proportion of large tuber yield percentage.

Noteworthy variation was observed among the different combinations of vermicompost levels and tuber sizes on seed tuber yield. The highest $(23.37 \mathrm{t} / \mathrm{ha})$ seed tuber yield was observed from $\mathrm{Vc}_{4} \mathrm{~T}_{5}$ and the lowest $\left(7.60 \mathrm{t} / \mathrm{ha}\right.$ ) was observed from $\mathrm{Vc}_{1} \mathrm{~T}_{1}$ (Table 1). The present study revealed that an increase in seedling tuber size gradually increased the yield of seed tubers. The results of present work are in agreement with the findings of Sultana et al. (2001) who stated that an increase in seedling tuber size gradually increase the yield of seed tubers.

Remarkable variation was observed among the different combinations of vermicompost levels and tuber sizes on non-seed tuber yield. The highest non-seed tuber yield $(9.76 \mathrm{t} / \mathrm{ha})$ was found from $V_{c_{2}} T_{3}$ and the lowest $\left(5.51 \mathrm{t} / \mathrm{ha}\right.$ ) non-seed tuber yield was found from $\mathrm{Vc}_{3} \mathrm{~T}_{1}$ (Table 1). The present study revealed that an increase in seedling tuber size gradually decreased the yield of nonseed tubers.

From the above discussion, it was observed that yield sharply increased with increasing vermicompost level up to $6 \mathrm{t} / \mathrm{ha}$ and, exhibited a statistically similar yield. Among the 20 
treatment combinations, although $\mathrm{Vc}_{4} \mathrm{~T}_{5}$ i.e., vermicompost $9 \mathrm{t} / \mathrm{ha}$ and tuber size $>40 \mathrm{~g}$ produced the highest yield ( $31.33 \mathrm{t} / \mathrm{ha}$ ) but $\mathrm{Vc}_{4} \mathrm{~T}_{4}$ and $\mathrm{Vc}_{3} \mathrm{~T}_{5}$ showed statistically similar yield. However, the potato farmers of Bangladesh may be benefited for potato cultivation by using vermicompost, ultimately, they can sell their quality potato to potato processing industry with a high price.

\section{References}

Adhikari RC 2005. Performance of different size true potato seed seedling tubers at Khumaltar. Nepal Agric. Res. J. 6: 35-38.

Alam MN, Jahan MS, Ali MK, Ashraf MA and Islam MK 2007. Effect of vermicompost and chemical fertilizers on growth, yield and yield components of potato in barind soils of Bangladesh. J. Appl. Sci. Res. 3: $1879-1888$.

Bangladesh Bureau of Statistics 2015. Yearbook of Agricultural Statistics. Ministry of Planning, Govt. of the People's Republic of Bangladesh.

Batra VK, Malik YS and Pandita ML 1992. Effect of growth regulators on establishment of potato seedlings in nursery beds in relation to seedling tuber production. J. Indian Potato Assoc. 19: 17-20.

Brammer H, Antoine J, Kassam AH and van Velthuizen HT 1988. Land resources appraisal of Bangladesh for agricultural development. Technical Reports Nos. 1-7, FAO/UNDP project BGD/81/035, Agricultural development advice. Dhaka, Bangladesh.

Burton WG 1989. The Potato. 3rd Edn. In: Propagation by true seed. Longman, Essex, UK, 68-83.

CIP 2008. Potato growth in accelerate. Retrieved January 20, 2016 from http://www.cipotato.org/potato

FAOSTAT 2020. Statistical Database. Food and Agricultural Organization of United Nations, Rome, Italy. Accessed on 19 May 2020. http://www.fao.org/faostat/en/\#data

Gangele P 2017. Effect of different level of potassium with and without vermicompost in potato variety kufri chipsona-1 (Doctoral dissertation, Rvskvv, Gwalior (MP)).

Gomez KA and Gomez AA 1984. Statistical Procedure for Agricultural Research. 2nd Edition. John Willey and Sons, New York, USA, pp. 139-180.

Harsharin S 1983. Influence of spacing and seed size on the growth, dry matter accumulation and uptake of NPK by potato crop. Indian Potato assoc. 10: 149-152.

Hoque ME 2010. In vitro tuberization in potato (Solanum tuberosum L.). Plant Omics J 3: 7-11.

Jenssen BH 1993. Integrated nutrient management: The use of organic and mineral fertilizer. In: The role of plant nutrients for sustainable food crop production in sub-saharan Africa, (ed.). H Van Reuler, and WH Prins, Leidschendam, The Netherlands pp. 89-105.

Joshi R, Singh J and Vig AP 2015. Vermicompost as an effective organic fertilizer and biocontrol agent: effect on growth, yield and quality of plants. Reviews in Environmental Science and Bio/Technology 14: 137-159.

Mondal MRI, Islam MS, Jalil MAB, Rahman MM, Alam MS and Rahman MHH 2011. Krishi Projukti Hat boi (Handbook of Agro-technology), 5th edition. Bangladesh Agricultural Research Institute, Gazipur1701, Bangladesh. p 307.

Senapati BK 1992. Vermitechnology: an option for recycling cellulosic waste in India. In: New Trends in Biotechnology. Oxford and IBH Publications Pvt. Co. Ltd., Calcutta. pp. 347-358.

Senesi N, Miano TM and Brunetti G 1996. Humic-like substances in organic amendments and effect of native soil humic substances. In: Humic substances in Terrestrial Ecosystem, Piccolo, A. (ed.). Elsevier Science. pp. 531-593.

Siddique MA and Rashid MH 2000. Role of true potato seed in potato development. Proc. Workshop on Potato Development in Bangladesh, ATDP/IFDC, Dhaka, Bangladesh, pp. 43-48.

Singh M 2010. Projection of potato export from India: a markov chain approach. Potato J 37: 48-55.

Sinha RK, Herat S, Chauhan K and Valani D 2009. Earthworms vermicompost: a powerful crop nutrient over the conventional compost \& protective soil conditioner against the destructive chemical fertilizers for food safety and security. American-Eurasian J. Agric. Environ. Sci. 5: 14-22. 
Statistix R 2013. Statistix 10 Analytical Software. Tallahassee, FL USA.

Sultana N, Bari MS and Rabbani MG 2001. Effect of seedling tuber size and depth of planting on the growth and yield of potato. Pakistan J. Biol. Sci. 4: 1205-1208.

United States Department of Agriculture 2014. Economic Research Service - Potatoes. retrieved on November 6, 2016.

Werner M and Cuevas R 1996. Vermiculture in Cuba. Biocycle. Emmaus, PA., JG Press. 37: 61-62.

(Manuscript received on 24 September, 2018; revised on 19 May, 2020) 